\title{
Microbial growth and activity during the initial stages of seagrass decomposition
}

\author{
L. K. Blum, A. L. Mills \\ Department of Environmental Sciences, University of Virginia, Charlottesville, Virginia 22903, USA
}

\begin{abstract}
Microbial $\mathrm{O}_{2}$ consumption and bacterial growth associated with decaying Zostera marina increased rapidly in the first $24 \mathrm{~h}$ of incubation at the sediment surface. During this period, the detrital complex lost $20 \%$ of its initial dry weight. An additional $20 \%$ of the original dry weight was lost in the next $13 \mathrm{~d}$, and $73 \%$ was lost over the entire 6 wk incubation period; changes in the rate of weight loss were consistent with changes in the patterns of bacterial activity. While the initial response of the detritus-associated bacteria was rapid and substantial, less than $7.5 \%$ of the detrital carbon lost during the first $48 \mathrm{~h}$ of incubation was metabolized (assimilated plus respired), although $52.6 \%$ was metabolized during the $28 \mathrm{~d}$ to $42 \mathrm{~d}$ period. Of the plant carbon metabolized, over $80 \%$ was mineralized to $\mathrm{CO}_{2}$. The results suggest that if bacterial transformation of plant litter is an important link in the transfer of primary production to aquatic food webs, water column bacteria function as a link and not the bacteria associated with detrital particles.
\end{abstract}

\section{INTRODUCTION}

The process of macrophyte decomposition can be interpreted to consist of 3 phases, including (1) an initial phase in which soluble materials are rapidly leached from the litter, (2) an intermediate phase during which microorganisms utilize less recalcitrant plant constituents such as hemicellulose and cellulose, (3) a third phase where litter weight loss occurs slowly as a result of microbial degradation of lignin and lignocellulose (Rublee \& Roman 1982, Valiela et al. 1984). Significant weight loss (15 to $55 \%$ of the initial weight) has been observed during the leaching phase (e.g. Planter 1970, Harrison \& Mann 1975, Godshalk \& Wetzel 1978, Kenworthy \& Thayer 1984, Valiela et al. 1984, Blum et al. 1988, Kenworthy et al. 1989).

The soluble compounds lost during leaching are generally considered to be highly labile, and thus readily available for microbial utilization. Although phenolic compounds in leachate may inhibit microbial activity (Harrison \& Chan 1980, Harrison 1982, Murray \& Hodson 1986), laboratory experiments with leachate from seagrasses (Thalassia testudinum, Syringodium filiforme, Zostera marina) showed rapid microbial growth on the dissolved materials (Robertson et al. 1982, Kenworthy \& Thayer 1984), Robertson et al. showed that DOC leached from seagrasses is rapidly converted to bacterial biomass, which lends support to the concept that these soluble materials are readily available to microorganisms. Thus, in addition to representing a major portion of the primary production, the leached material also has the potential to be converted quickly and possibly very efficiently via bacterial secondary production to a form that is available to higher trophic levels.

Little is known about the contribution to secondary production made by the carbon lost during the leaching phase because of the time scales associated with field decomposition studies. Experiments often cover periods of months to years; sampling intervals are rarely more frequent than bi-weekly, and are most often monthly or longer. While appropriate data on some aspects of decomposition can be derived from such studies, detailed examination of rapidly occurring phenomena such as microbial assimilation of dissolved leachates may not be adequately addressed.

Thus, the object of this study was to examine the conversion of the rapidly leached plant material to microbial cells by the community of microorganisms that is associated with the detritus during the initial stages of submerged litter decay. Those microorganisms on detrital surfaces should be in the ideal position to take advantage of dissolved organic carbon (DOC) as it moves out of the detrital particles. A variety of methods was used to evaluate the response of the microbial community to the leached materials. The 
results indicate that very little of this material was converted to microbial cells

\section{MATERIALS AND METHODS}

To compare changes in microbial community utilization of macrophyte carbon during decomposition, the seagrass Zostera marina was collected and allowed to decompose in litter bags anchored at the sediment surface. The seagrass was collected as whole plants with primarily green and some yellow leaves. Collected leaves were stored in an ice chest containing continuously aerated sea water. Approximately $25 \mathrm{~g}$ (wet weight) of fresh plant material were placed in each litter bag according to the method described by Zieman (1968). Ratios of fresh weight: dry weight: ash-free dry weight were determined using the procedure of Robertson (1982). Numbered litter bags (nylon mesh with $1 \mathrm{~mm}$ openings) were attached to a line anchored to the sediment surface in approximately $1 \mathrm{~m}$ of water near an extensive $Z$. marina bed in the shoal area between Hungars and Occohannock Creeks on the lower eastern shore of Chesapeake Bay (USA). Litter bags were prepared and returned to the water within $24 \mathrm{~h}$ of the initial plant collection. The plant material was kept moist during this entire time.

Bags were withdrawn daily for $14 \mathrm{~d}$, and after 28 and $41 \mathrm{~d}$ beginning in mid-July. At each sampling time, 3 bags were retrieved, and the contents were washed free of sediment and animal matter with water collected from the experimental site. The contents of each bag were weighed, and sub-samples of the detritus were withdrawn for determination of litter dry weight loss, bacterial abundance and biovolume (for calculation of biomass), bacterial productivity, and microbial activity (oxygen consumption).

Determination of the decay rate. The rate of litter decay was measured as the ash-free dry weight (AFDW) loss over time. After determining the total wet weight of material in each bag, 2 subsamples were removed from each of the 3 litter bags and weighed. The subsamples were then dried at $90^{\circ} \mathrm{C}$ for $12 \mathrm{~h}$, reweighed, and the AFDW determined as the weight loss after combustion $\left(500^{\circ} \mathrm{C}\right.$ for $\left.12 \mathrm{~h}\right)$. For each subsample, the ratio wet weight: dry weight: ash-free dry weight was determined and the mean ratio of the 2 subsamples used to convert the entire wet weight of the contents of the respective bags to ash-free dry weight.

Determination of bacterial abundance and biomass. Two subsamples of ca $1 \mathrm{~g}$ (wet weight) each were removed from each litter bag. Each subsample was placed in $10 \mathrm{ml}$ of filtered $(0.2 \mu \mathrm{m}$ pore diam. used throughout) estuarine salt solution (FSW, 20\%) containing $2 \%$ formaldehyde. Samples were refrigerated, and within $2 \mathrm{wk}$ of sampling, bacterial abundance was determined using the acridine orange direct count (AODC) technique (Hobbie et al. 1977) as modified by Rublee et al. (1978) for detritus. Bacterial biovolume was determined by measuring a minimum of 100 cells in photomicrographs for each sample. Thus, a minimum of 300 cells were measured for each sampling interval. Photographs were also taken of a stage micrometer and used to determine the total magnification of the projector/camera/microscope system. To calculate the volume of rod-shaped cells, the cells were assumed to be cylindrical with hemispherical ends, i.e., VOL $=\pi / 4 \times w^{2}(1-w / 3) ;$ where VOL $=$ cell volume; $w$ $=$ width; $I=$ length (Krambeck et al. 1981). This formula was also used to estimate biovolume for coccoid cells. Bacterial mass was calculated as (dry-mass density) $\times$ (biovolume $\times$ unit $^{-1}$ substrate mass) assum-

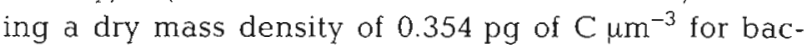
teria (Bjørnsen 1986).

Determination of microbial activity. Microbial oxygen consumption was measured by removing a subsample of detritus from the litter bags and placing ca $1 \mathrm{~g}$ (wet weight) in a $300 \mathrm{ml}$ BOD bottle. Three BOD bottles were prepared from each litter bag. Water collected from within the grass bed at the experimental site was filtered and sparged with air for ca $1 \mathrm{~h}$ prior to filling the BOD bottles. A set of 3 BOD bottles containing filtered, aerated sea water was included as a control. All of the bottles were incubated in the dark for $3 \mathrm{~h}$ at in situ water temperature. The oxygen concentration at the beginning and end of the incubation was determined using an Orbisphere Model 2714 oxygen meter with a Model 2105.01 sensor which is insensitive to interference by $\mathrm{NH}_{3}, \mathrm{H}_{2} \mathrm{~S}, \mathrm{SO}_{2}$, and $\mathrm{CO}_{2}$.

Bacterial production. The rate of thymidine incorporation into bacterial DNA was used as a measure of bacterial growth rate and carbon turnover. The technique of Pollard \& Moriarty (1984) with some modification was used. Approximately $0.5 \mathrm{~g}$ (wet weight) detritus were placed in a small vial containing $10.0 \mathrm{ml}$ of filter-sterilized sea water collected from within the grass bed at the experimental site. Ten vials were prepared from each litter bag. Tritiated thymidine $\left({ }^{3} \mathrm{H}\right.$ $\mathrm{TdR})$ was added $(20 \mu \mathrm{Ci})$ and cold thymidine was added to yield a final concentration of $60 \mathrm{nM}$. In preliminary experiments with Zostera marina detritus, ${ }^{3} \mathrm{H}$ TdR incorporation was saturated over a range of 20 to $100 \mathrm{nM}$ thymidine. Since the concentration at which saturation occurs is dependent on the size of the bacterial population and the growth rate (Pollard \& Moriarty 1984), we selected a concentration of $60 \mathrm{nM}$ for our experiments to allow for variation in bacterial abundance and growth rates between the preliminary experiments and those measured during the various stages of decomposition. The contents of 5 of the 10 
vials from each litter bag were immediately killed with buffered formalin (4\% $\mathrm{v} / \mathrm{v}$ formalin final concentration per vial). The live samples were incubated for $20 \mathrm{~min}$ and the thymidine incorporation stopped by adding buffered formalin. The vials were immediately placed on ice and stored at $4{ }^{\circ} \mathrm{C}$. DNA extraction and purification was done within $2 \mathrm{wk}$.

In this experiment, the radioactively-labeled macromolecules that were insoluble in cold trichloroacetic acid (TCA), but hydrolyzed in hot TCA, were collected as described by Pollard \& Moriarty (1984). The contents of each vial were filtered through $25 \mathrm{~mm}$ polycarbonate filters $(0.2 \mu \mathrm{m}$ pore size) and washed 5 times with $10 \mathrm{ml}$ of ice-cold $3 \%$ TCA. The filters were placed in $20 \mathrm{ml}$ glass scintillation vials with $10 \mathrm{ml}$ of $5 \%$ TCA and hydrolyzed at $100^{\circ} \mathrm{C}$ for $30 \mathrm{~min}$. Radioactivity was counted in a sample of the hydrolysate. Preliminary experiments indicated that there were no differences between the method described here and DNA extracted exactly as described by Moriarty \& Pollard (1981) for incubations of less than 30 min. To calculate bacterial productivity, we chose to use the conversion factors obtained by Moriarty \& Pollard (1981) for bacteria associated with Zostera capricorni of $1.3 \times 10^{18}$ cells ( $\mathrm{mol}{ }^{3} \mathrm{H}$-TdR incorporated) ${ }^{-1}$.

During all of the procedures, the detritus was handled as little as possible and care was taken not to break the decaying leaves. In preliminary experiments, we examined the effect of cutting the detritus into small pieces on $\mathrm{O}_{2}$ consumption and ${ }^{3} \mathrm{H}$-TdR incorporation. In both cases, the effect of breaking or cutting the leaf litter at the time of sampling significantly increased the rates of $\mathrm{O}_{2}$ consumption and thymidine incorporation.

Determination of normalization factors. Because radioactive samples could not be safely combusted in our laboratory, the parameters were compared on a dry-weight basis. Dry weights were determined by filtering the contents of the reaction vessel containing the plant material onto pre-dried and weighed Whatman GF/F filters. The filters and detritus were dried at $90^{\circ} \mathrm{C}$ for $24 \mathrm{~h}$ and reweighed.

\section{RESULTS}

\section{Detritus weight loss}

A substantial portion of the litter weight was lost very rapidly (Fig. 1A). After the first 24 h of incubation, only $80 \%$ of the initial detritus weight remained in the litter bags. Subsequent weight loss occurred at a slower rate with $30 \%$ of the material remaining after $41 \mathrm{~d}$ of incubation. Both linear and exponential (first-order) decay models fit the data similarly between Days 1 to $41\left(\mathrm{r}^{2}\right.$ values $=0.92$ and 0.94 , respectively), while the expo- nential model yielded the best fit when the weight loss data from Day 0 were included $\left(\mathrm{r}^{2}=0.93\right.$ and 0.85 , exponential and linear models, respectively).

\section{Bacterial abundance and biomass}

Bacterial abundance increased throughout the course of the experiment (Fig. 1B). On the other hand, the biomass decreased initially (Days 1 to 4 ), then generally increased throughout the remainder of the incubation, although the biomass was quite variable from day to day (Fig. 1A). The rate of increase in bacterial biomass was not as rapid as that of bacterial abundance, and was a result of a consistent, although gradual, decrease in the mean cell size throughout the course of the experiment (Day 1, $0.34 \mu \mathrm{m}^{3}$; Day 4 ,

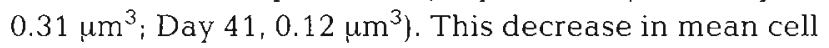
biovolume may have been an indication that either available carbon or inorganic nutrients were limiting (Morita 1985, 1986).

\section{Microbial activity measurements}

The greatest rates of oxygen consumption, $4 \mathrm{mg} \mathrm{O}$ (g dry detritus) $)^{-1} \mathrm{~h}^{-1}$, were associated with the initial $24 \mathrm{~h}$ of the incubation (Fig. 1C). The initial oxygen consumption was also characterized by a high degree of variation among replicate samples. From the peak in oxygen consumption during the first day, consumption decreased to $3 \mathrm{mg} \mathrm{O}$ (g dry detritus) $)^{-1} \mathrm{~h}^{-1}$ by the second day and stabilized at approximately $2 \mathrm{mg} \mathrm{O}_{2}$ ( $g$ dry detritus) $)^{-1} h^{-1}$ by $6 \mathrm{~d}$ of decomposition.

\section{Thymidine incorporation}

The rate of thymidine incorporation measured for bacteria associated with freshly collected seagrass was low (50 DPM (g dry detritus) ${ }^{-1}$ for a 20 min incubation) (Fig. 1D). Within $24 \mathrm{~h}$, the rate of incorporation increased to 1400 DPM ( $g$ dry detritus) $)^{-1}$ (20 min incubation), the maximum value measured during the experiment. The peak in thymidine incorporation coincided with the greatest decrease in litter weight loss, and greatest increase in oxygen consumption. Subsequent rates of thymidine incorporation were lower than the peak activity at Day 1, although after Day 9, there was a consistent increase in incorporation.

\section{Bacterial turnover time}

Bacterial turnover time was calculated from the abundance and thymidine incorporation data by divid- 


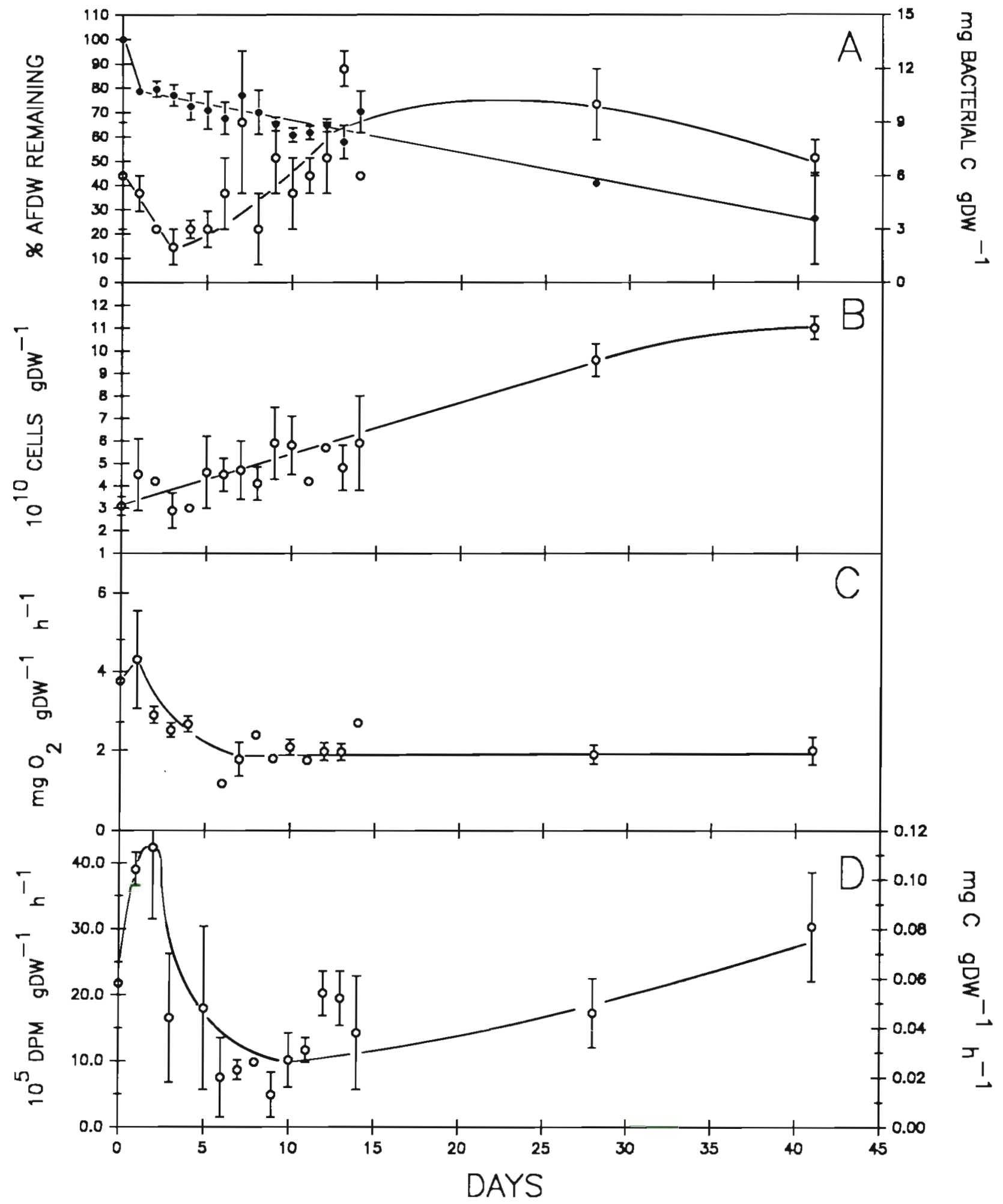

Fig. 1. (A) Zostera marina weight loss (expressed as percentage of ash-free dry weight remaining); bacterial biomass calculated from bacterial abundance, biovolume (see text), and a conversion factor of $0.354 \mathrm{pg} \mathrm{C}$ per bacterial cell. (B) Number of bacterial cells (AODC) associated with decaying $Z$. marina litter. (C) Microbial oxygen consumption; data for Day 5 of the experiment are missing. (D) Incorporation of tritiated thymidine into DNA based on a 20 min incubation; data for Day 4 are missing. For all panels, error bars are 1 standard deviation $(n=3)$; for points with no error bar, the standard deviation is less than the size of the symbol. Curves for all panels were fit by eye and are only intended to illustrate general trends 
ing the bacterial standing crop by cell production. Bacterial production was calculated using a conversion factor of $1.3 \times 10^{18}$ cells $\mathrm{mol}^{-1}$ thymidine incorporated. This conversion factor is conservative in comparison with literature values $\left(0.9 \times 10^{18}\right.$ to $68 \times 10^{18} \mathrm{cells} \mathrm{mol}^{-1}$ thymidine), and falls within the range ( 1 to $6 \times 10^{9}$ cells $n^{n} \mathrm{~mol}^{-1}$ thymidine) determined by Cole et al. (1989) to be the limits for the thymidine conversion factor in Mirror Lake.

Turnover times were most rapid during the first $3 \mathrm{~d}$ of the incubation $(6.3 \pm 1.4$ d) (Fig. 2 A). From Day 3 to 10 , the daily estimates of doubling time were highly variable ( $\pm 11.3 \mathrm{~d}$ ) with a mean of $45.8 \mathrm{~d}$. During the later stages of decay, both the variation in daily estimates and mean turnover time were less than those for the intermediate stage, i.e. $22.5 \pm 6.5 \mathrm{~d}$ for Days 11 to 41 .

\section{Bacterial efficiency}

Bacterial efficiency for each day was calculated as the change in bacterial cell carbon (based on the change in bacterial biomass) divided by the change in bacterial cell carbon plus the respired carbon (based on oxygen consumption data). It was assumed that grazing was negligible and that all of the oxygen consumed was respired by bacteria at a ratio of $1 \mathrm{C}$ atom to 1 molecule of $\mathrm{O}_{2}$ (i.e. $\mathrm{RQ}=1$ ). Although organisms other than bacteria may have contributed to oxygen consumption, in other experiments (unpubl. own data, Blum et al. 1988) the biomass of fungi associated with decaying seagrass detritus was often undetectable during the initial stages of decay ( 0 to $14 \mathrm{~d}$ ) and was less than $1 \%$ of the bacterial biomass at later stages of decay (after 28 d) so that it is unlikely that fungi consumed a significant amount of $\mathrm{O}_{2}$. In addition, prior to the oxygen consumption incubations, all visible macroorganisms were removed from the detritus to eliminate these organisms as $\mathrm{O}_{2}$ consumers. The contribution of protozoans to community respiration may also have been minimal if, as suggested by Cole et al. (1988), protozoan respiration is 4 to 6 times less than bacterial respiration. Yet, the possibility that respiration by organisms other than bacteria accounted for a significant portion of the $\mathrm{O}_{2}$ consumption measured cannot be eliminated on the basis of any direct measurement. Thus, the bacterial oxygen consumption may be overestimated, and therefore the efficiencies reported here may underestimate the actual value.

Bacterial efficiencies (Fig. 2B) appear to segregate into 3 stages. Initially, during the period of most rapid litter-weight loss, the efficiencies averaged $8.1 \%$. The intermediate stage, Days 4 to 14 , was characterized by the highest efficiencies during the course of the experiment (mean of $20.3 \%$ ) but the values were quite vari-

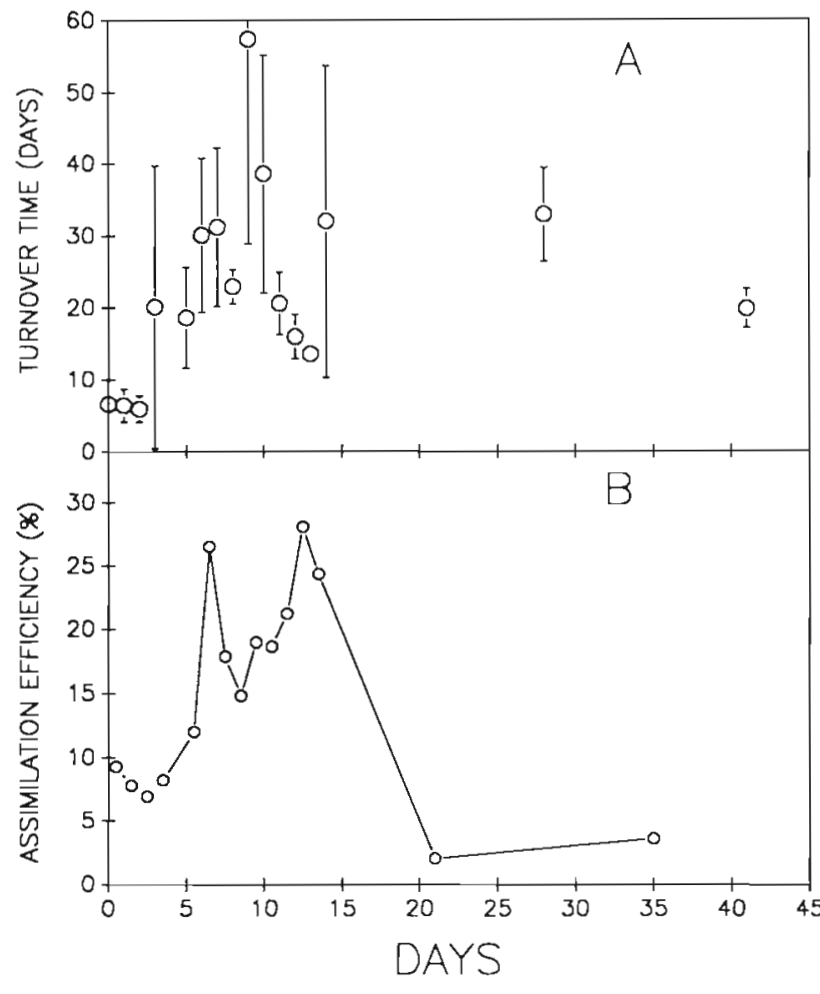

Fig. 2. (A) Bacterial turnover time calculated from bacterial abundance and thymidine incorporation rates; turnover could not be calculated for Day 4 due to missing thymidine incorporation data; error bars are 1 standard deviation ( $n=3$ ); for points with no error bar, the standard deviation is less than the size of the symbol. (B) Bacterial assimilation efficiency, calculated as the change in bacterial cell carbon (based on the change in bacterial biomass) divided by the change in bacterial cell carbon plus the respired carbon (based on oxygen consumption data)

able (range of 12.0 to $28.0 \%$ ). The latest stage of decay was typified by very low efficiencies that are often associated with degradation of more recalcitrant plant constituents such as lignins, phenolic compounds, and waxes.

\section{DISCUSSION}

The results of this study indicate that the microbial community on the surface of detritus responds rapidly to DOC leached during the initial stage of decay. Increases in bacterial abundance and productivity, and increases in microbial $\mathrm{O}_{2}$ consumption are consistent with the observed patterns of detrital weight loss.

The oxygen consumption and bacterial productivity data reported here support the hypothesis that microbial activity is greatest during the early stages of decay when highly labile compounds are thought to be leached from detrital materials. However, the high degree of variability associated with $\mathrm{O}_{2}$ consumption 
measurements, especially for the 24 h samples, makes it difficult to demonstrate a microbial response to weight loss based on $\mathrm{O}_{2}$ consumption alone. There are several factors that might have contributed to the variability associated with the oxygen consumption measurements made during the first $24 \mathrm{~h}$. For example, Robertson et al. (1982) reported that fresh green seagrass material can continue to photosynthesize and produce oxygen following harvest. Additionally, the plants may also exhibit a weight gain during the initial stages of decomposition (Robertson 1982). It is unlikely that these processes were occurring in the present study because the incubations were done in the dark, and there was a significant amount of litter weight lost during the initial $24 \mathrm{~h}$. During plant senescence and death, however, rates of respiration frequently increase (Bidwell 1974) which could contribute to the variability measured in the first $24 \mathrm{~h}$ in this experiment. Other measures of microbial response to the leached DOC, including increased bacterial abundance and productivity, are consistent with the oxygen consumption measurements and lend support to the suggestion that the rates of $\mathrm{O}_{2}$ consumption measured resulted primarily from microbial activity.

Examination of the response of the microbial community during the initial stages of decomposition may provide a means of determining the proportion of the labile material released during this period that is ultimately available to higher trophic levels. The problems associated with studies attempting to examine the microbial contribution to carbon cycling are numerous and controversial; they include estimation of the thymidine (or any nucleotide) conversion factor, the factor for cell carbon content, and the growth efficiency of the bacterial community (i.e. the amount of cell carbon produced per unit of primary-produced carbon metabolized (respired + assimilated)). There is some evidence from the iiterature that the thymidine conversion factor is constant among systems (Fuhrman \& Azam 1982), or that the thymidine conversion factor and carbon conversion factor are at least limited to a narrow range for any given ecosystem (Cole et al. 1989). We have assumed these factors to be constant throughout the course of our experiment, and we have used these numbers to estimate bacterial turnover time (time to produce an equivalent amount of biomass), assimilation efficiency, and the amount of plant carbon metabolized by the detritus-associated bacteria.

Turnover times reported here are longer than doubling times generally reported in the literature for watercolumn bacteria measured by ${ }^{3} \mathrm{H}-\mathrm{Tdr}$ incorporation, frequency of dividing cells, or change in the standing crop (Table 1). One explanation for the relatively long doubling times reported here is that only a small fraction of the bacterial community was active (Kirchman et al. 1982). Predictions of the daily changes in bacterial abundance calculated from the daily production estimates were correlated with the measured changes in bacterial abundance (comparison not shown, $\mathrm{r}^{2}=$ 0.96). The high degree of correlation between these 2 measures of bacterial growth suggests that: (1) the thymidine conversion factor used is reasonable and grazing is negligible, or (2) the thymidine conversion factor is too low, underestimating production, and the agreement between the predicted values and measured values is a result of grazing. No measures of grazer abundance or grazing rate were attempted during this study.

The bacterial efficiencies measured in the present study (2 to $20 \%$ ) are low in comparison with generally accepted values (10 to $87 \%$ ) for planktonic bacterial growth yields based on radiotracer studies with simple dissolved organic compounds (from values cited in Bjørnsen 1986). One explanation of these differences is that we have overestimated bacterial respiration (as described above). An alternate explanation is that efficiencies may be substantially lower on naturally occurring, complex substrates such as decaying macrophytes than on simple dissolved organics.

The growth yields we report are within the range that others (Lucas et al. 1981, Newell et al. 1981. Stuart et al. 1981, Linley \& Newell 1984) have measured on complex, natural substrates. For example, Kenworthy et al. (1989) reported microbial efficiencies of 3 to $6 \%$ for the seagrass Halophila decipiens during the first $6 \mathrm{~d}$ of in situ decomposition. However, our values are substantially lower than those of Benner et al. (1988) where conversion efficiencies were $30 \%$ for lignocellulose derived from Spartina alterniflora and Carex walteriana. The latter values probably represent the maximum carbon conversion efficiency since the lignocellulose was extracted, ground to a maximum particle size of $425 \mu \mathrm{m}$, and incubated in the laboratory. Benner et al. (1988) argue that the discrepancy between their conversion efficiencies and those from earlier studies (e.g. Linley \& Newell 1981) are a result of differences in the value used to convert bacterial biovolume to carbon content $\left(0.22\right.$ vs $0.11 \mathrm{~g} \mathrm{C} \mathrm{cm}^{-3}$, Benner et al. 1988 , and Linley \& Newell 1984, respectively). The biovolume-tocarbon content conversion factor used in this study was that of Bjornsen (1986), $0.35 \mathrm{~g} \mathrm{C} \mathrm{cm}^{-3}$. Thus, the values reported here fall in the low range of those observed by others and likely represent a conservative estimate of bacterial growth efficiencies on particulate plant detritus.

The low bacterial carbon conversion efficiencies associated with particulate vascular plant detritus suggest that a substantial portion of the primary production is mineralized, thus supporting the contention that macrophyte carbon contributes little to aquatic food 
webs. Yet few studies have examined the responses of microbial communities to the initial stages of vascular plant decay when up to 20 to $30 \%$ of the plant carbon is lost, presumably as highly labile, dissolved organic material which may be quickly and efficiently assimilated by the microbial community. Because of their intimate contact with the plant, microorganisms on the surface of the litter would be the first organisms to come into contact with these relatively nutrient- and energy-rich compounds.

Knowledge of the fate of these compounds (are they rapidly mineralized or do they provide an important source of nutrients and energy for bacterial secondary production?) would provide some insight into the functional role of the detrital-associated microbial community during the initial stage of decay. Thus, a simple carbon budget [detritus $C$ loss and total $C$ metabolized (assimilated+respired)] was constructed using the assumption: (1) the organic carbon content of the lost detrital material was the same as that of the remaining material $(40 \%$ as determined by Carlo-Erba $\mathrm{C}, \mathrm{H}, \mathrm{N}$ analysis - unpubl. own data); (2) grazing of the bacterial biomass was insignificant; (3) oxygen consumption was a result of bacterial respiration alone (see reservations discussed above); (4) fragmentation and loss of detrital material from the litter bags was unimportant particularly during the first $14 \mathrm{~d}$ of the experiment. Assumption (4) was based on qualitative observations of the condition of the detritus when it was removed from the litter bag. During the entire experiment there was no evidence of herbivory on the grass blades and the structural integrity of the leaves was maintained, although the decaying leaves were quite fragile by the end of the experiment and required careful handling to insure removal of all of the material from the litter bags.

Detritus-associated bacterial activity (assimilation + respiration) consistently accounted for less than $10 \%$ of the detrital carbon lost during the first $14 \mathrm{~d}$ of the experiment (Fig. 3). Even during the first 24 to $48 \mathrm{~h}$ leaching phase, the bacteria metabolized only $7.5 \%$ of the carbon released. In contrast, during the later stages of decay, $52.6 \%$ of the detrital carbon flowed through the bacterial loop. These data suggest that, although the detritus-associated bacteria rapidly respond to the loss of dissolved materials as evidenced by increased growth rate, oxygen consumption, and increased abundance, the microorganisms in intimate contact with detritus were not able to utilize a significant portion of the leached compounds.

One explanation for these results is that a large fraction of the DOC released during the first $14 \mathrm{~d}$ is more recalcitrant than generally accepted. Evidence to the contrary was reported by Robertson et al. (1982). In their study, $65 \%$ of seagrass leachates were utilized by

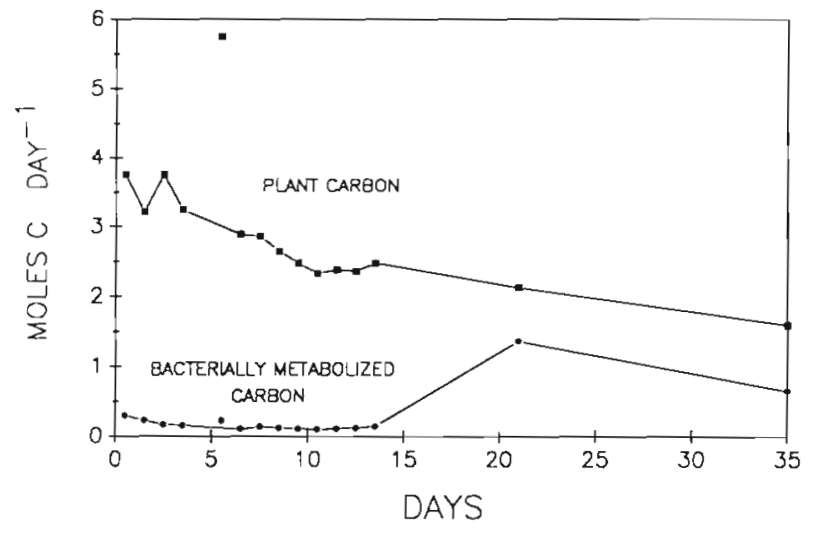

Fig. 3. Relationship between the moles of plant carbon lost per day (filled squares) and the amount of plant carbon metabolized (assimilated + respired) by the bacterial community per day (filled circles). The data point for Day 5, plant carbon lost, was considered to be an outlier (although plotted on the graph) and was not used to draw the line. The percentage of the plant carbon lost each day that moves through the microbial loop can be calculated as (ratio of bacterially metabolized carbon to the plant carbon lost) $\times 100$. Data for Day 4 are missing

the microbial community in $2 \mathrm{~d}$, and after $14 \mathrm{~d}, 80 \%$ of the leachate had been converted to microbial cells or mineralized. An alternate explanation of the low microbial utilization of leached materials is that movement of the leached materials away from the detritus particles occurs so rapidly that the attached microorganisms are able to take up only a small portion of the plant material. Thus, leachate from particulates would become an important source of dissolved compounds for bacterioplankton metabolism, especially in water over densely vegetated sediments.

The bacterial community associated with seagrass detritus responds rapidly to the release of leachable, water-soluble components. However, little of the released material is metabolized by the bacterial community, and the portion of the dissolved material that is metabolized is primarily mineralized. Even during the later phases of decay, when $50 \%$ of the detrital material passes through the bacteria and the carbon conversion efficiency of the material is exceptionally low, little of the plant material is used to produce bacterial biomass. If bacterial transformation of vascular plant material is an important link in the transfer of primary production to aquatic food webs, it is the water-column bacteria that function as a link and not those bacteria that are closely associated with detrital particles. The dissolved material leached from macrophyte detritus may also contribute to the observations that bacterial production often exceeds phytoplankton production (Ducklow \& Peele 1987). 
Acknowledgements. This work is a result of research sponsored by NOAA Office of Sea Grant, US Department of Commerce, under Grant No. NA86AA-D-SGO42 to the Virginia Graduate Marine Science Consortium and Virginia Sea Grant College Program. Logistical support was provided by the University of Virginia's Long-Term Ecological Research Project at the Virginia Coast Reserve. The US Government is authorized to produce and distribute reprints for governmental purposes notwithstanding any copyright notation that may appear hereon.

\section{LITERATURE CITED}

Bell, R. T., Ahlgren, I. (1987). Thymidine incorporation and microbial respiration in the surface sediment of a hypereutrophic lake. Limnol. Oceanogr. 32: 476-482

Benner, R., Lay, J., K'nees, E., Hodson, R. E. (1988). Carbon conversion efficiency for bacterial growth on lignocellulose: implications for detritus-based food webs. Limnol. Oceanogr. 33: 1514-1526

Bidwell, R. G. S. (1974). Plant physiology. Macmillan Publishing Co., Inc., New York

Bjornsen, P. K. (1986). Automatic determination of bacterioplankton biomass by image analysis. Appl environ. Microbiol. 51: 1199-1204

Bjørnsen, P. K. (1986). Bacterioplankton growth yield in continuous seawater cultures. Mar. Ecol. Prog. Ser. 30: 191-196

Blum, L. K., Mills, A. L., Zieman, J. C., Zieman, R. T. (1988). Abundance of bacteria and fungi in seagrass and mangrove detritus. Mar. Ecol. Prog. Ser. 42: 73-78

Cole, J. J., Caraco, N. F., Strayer, D. L., Ochs, C., Nolan, S. (1989). A detailed organic carbon budget as an ecosystemlevel calibration of bacterial respiration in an oligotrophic lake during midsummer. Limnol. Oceanogr. 34: 286-296

Cole, J. J., Findlay, S., Pace, M. L. (1988). Bacterial production in fresh and saltwater ecosystems: a cross-system overview. Mar. Ecol. Prog. Ser. 43: 1-10

Ducklow, H. W. (1982). Chesapeake Bay nutrient and plankton dynamics. 1. Bacterial biomass and production during spring tidal destratification in the York River, Virginia, estuary. Limnol. Oceanogr. 27: 651-659

Ducklow, H. W., Peele, E. (1987). Bacterial carbon pools and fluxes in Chesapeake Bay plankton. In: Mackiernan, G. B. (ed.) Dissolved oxygen in the Chesapeake Bay: processes and effects. Maryland Sea Grant Publication UM-SG-TS87-03, Univ. Maryland, College Park, MD, p. 81-85

Findlay, S., Meyer, J. L. (1984). Significance of bacterial biomass and production as an organic carbon source in lotic detrital systems. Bull. mar. Sci. 35: 318-325

Fuhrman, J. A., Azam, F. (1982). Thymidine incorporation as a measure of heterotrophic bacterioplankton production in marine surface waters: evaluation and field results. Mar. Biol. 66: 109-120

Fuhrman, J. A., Ducklow, H. W., Kirchman, D. L., Hudak, J., McManus, G. B., Kramer, J. (1986). Does adenine incorporation into nucleic acids measure total microbial production? Limnol. Oceanogr. 31: 627-636

Godshalk, G. L., Wetzel, R. G. (1978). Decomposition of aquatic angiosperms. I. Dissolved components. Aquatic Bot. 5: 281-300

Harrison, P. G. (1982). Control of microbial growth and of amphipod grazing by water-soluble compounds from leaves of Zostera marina. Mar. Biol. 67: 225-230
Harrison, P. G., Chan, A. T. (1980). Inhibition of the growth of micro-algae and bacteria by extracts of eelgrass (Zostera marina) leaves. Mar. Biol. 61: 21-26

Harrison, P. G., Mann, K. H. (1975). Detritus formation from eelgrass (Zostera marina L.): the relative effects of fragmentation, leaching, and decay. Limnol. Oceanogr. 20: 924-934

Hobbie, J. E., Daley, R. J., Jasper, S. (1977). Use of Nuclepore filters for counting bacteria by fluorescence microscopy. Appl. environ. Microbiol. 33: 1225-1228

Kenworthy, W. J., Currin, C. A., Fonseca, M. S., Smith, G. (1989). Production, decomposition, and heterotrophic utilization of the seagrass Halophila decipiens in a submarine canyon. Mar. Ecol. Prog. Ser. 51: 277-290

Kenworthy, W. J., Thayer, G. W. (1984). Production and decomposition of the roots and rhizomes of seagrasses, Zostera marina and Thalassia testudinum, in temperate and subtropical marine ecosystems. Bull. mar. Sci. 35: $364-379$

Kirchman, D. (1983). The production of bacteria attached to particles suspended in a freshwater pond. Limnol. Oceanogr. 28: 858-872

Kirchman, D., Ducklow, H., Mitchell, R. (1982). Estimates of bacterial growth from changes in uptake rate and biomass. Appl. environ. Microbiol. 44: 1296-1307

Kirchman, D. L., Hoch, M. P. (1988). Bacterial production in the Delaware Bay estuary estimated from thymidine and leucine incorporation rates. Mar. Ecol. Prog. Ser. 45: $169-178$

Krambeck, C., Krambeck, H.-J., Overbeck, J. (1981). Microcomputer-assisted biomass determination of plankton bacteria on scanning electron micrographs. Appl. environ. Microbiol. 42: 142-149

Linley, E. A. S., Newell, R. C. (1981). Heterotrophic communities associated with the degradation of kelp debris. Kieler Meeresforsch. 5: 343-355

Linley, E. A. S., Newell, R. C. (1984). Estimates of bacterial growth yields based on plant detritus. Bull. mar. Sci. 35: 409-425

Lucas, M. I., Newell, R. C., Velimirov, B. (1981). Heterotrophic utilization of kelp (Ecklonia maxima and Laminaria palLida) II. Differential utilization of dissolved organic components from kelp mucilage. Mar Ecol. Prog. Ser. 4: 43-55

Moriarty, D. J. W. (1986). Bacterial productivity in ponds used for culture of penaeid prawns. Microbial Ecol. 12: 259-269

Moriarty, D. J. W., Pollard, P. C. (1981). DNA synthesis as a measure of bacterial productivity in seagras sediments. Mar. Ecol. Prog. Ser. 5: 151-156

Moriarty, D. J. W., Boon, P. I., Hansen, J. A., Hunt, W. G., Poiner, I. R., Pollard, P. C., Skyring, G. W., White, D. C. (1985). Microbial biomass and productivity in seagrass beds. Geomicrobiology J. 4: 21-51

Morita, R. Y. (1985). Starvation and miniaturization of heterotrophs, with special emphasis on maintenance of the starved viable state. In: Fletcher, M., Floodgate, G. (eds.) Bacteria in the natural environment. Academic Press, New York, p. 111-130

Morita, R. Y. (1986). Starvation-survival: the normal mode of most bacteria in the ocean. In: Megusar, F., Gantar, M. (eds.) Perspectives in microbial ecology. Proceedings of the Fourth International Symposium on Microbial Ecology, Slovene Soc. Microbiol., Ljubljana, Yugoslavia, p. 243-248

Murray, R. E., Hodson, R. E. (1986). Influence of macrophyte decomposition on growth rate and community structure of Okefenokee swamp bacterioplankton. Appl. environ. Microbiol. 51: 293-301 
Newell, R. C., Linley, E. A. S., Lucas, M. I. (1983). Bacterial production and carbon conversion based on saltmarsh plant debris. Estuarine coast. Shelf Sci. 17-405-419

Newell, R. C., Lucas, M. I., Linley, E. A. S. (1981). Rate of degradation and efficiency of conversion of phytoplankton debris by marine microorganisms. Mar. Ecol. Prog. Ser 6: $123-136$

Newell, S. Y., Christian, R. R. (1981). Frequency of dividing cells as an estimator of bacterial productivity. Appl. environ. Microbiol. 42: 23-31

Planter, L. R. (1970). Elution of mineral components out of dead reed Phragmites communis Trin. Pol. Arch. Hydrobiol. 17: 357-362

Pollard, P. C., Moriarty, D. J. W. (1984). Validity of the tritiated thymidine method for estimating bacterial growth rates: measurement of isotope dilution during DNA synthesis. Appl. environ. Microbiol. 48: 1076-1083

Robertson, M. L. (1982). The effects of species origin and environmental setting on the decomposition of two tropical seagrasses, Thalassia testudinum and Syringodium filiforme. M. S. thesis, Univ. of Virginia, Charlottesville

Robertson, M. L., Mills, A. L., Zieman, J. C. (1982). Microbial synthesis of detritus-like particulates from dissolved organic carbon released by tropical seagrasses. Mar. Ecol. Prog. Ser. 7: 279-285

This article was presented by DrS. Y Newell, Sapelo Island, Georgia, USA
Rublee, P. A., Cammen, L., Hobbie, J. E. (1978). Bacteria in a North Carolina salt marsh: standig crop and importance in the decomposition of Spartina alterniflora. UNC Sea Grant Publ. \# UNC-SG-78-11. Aug. 1978. Univ. North Carolina

Rublee, P. A., Roman, M. R. (1982). Decomposition of turtlegrass (Thalassia testudinum Konig) in flowing sea-water tanks and litterbags: compositional changes and comparison with natural particulate matter. J. exp. mar. Biol. Ecol. 58: $47-58$

Scavia, D., Laird, G. A., Fahnenstiel, G. L. (1986). Production of planktonic bacteria in Lake Michigan. Limnol. Oceanogr. 31 612-626

Stuart, M., Lucas, M. I., Newell, R. C. (1981). Heterotrophic utilization of particulate matter from kelp, Laminaria pallida. Mar. Ecol. Prog. Ser. 4: 337-348

Valiela, I., Wilson, J., Buchsbaum, R., Rietsma, C., Bryant, D., Foreman, K., Teal, J. (1984). Importance of chemical composition of salt marsh litter on decay rates and feeding by detritivores. Bull. mar. Sci. 35: 261-269

Zieman, J. C. (1968). A study of the growth and decomposition of the seagrass Thalassia testudinum. M.S. thesis. Univ. of Miami, Coral Gables

Manuscript first received: April 17, 1990

Revised version accepted: November 14, 1990 